\title{
German Invasion and Spy Scares in Ireland, 1890s-1914: Between Fiction and Fact
}

Jérôme Aan de Wiel

\section{Q OpenEdition \\ 1 Journals}

\section{Electronic version}

URL: http://journals.openedition.org/etudesirlandaises/2936

DOI: 10.4000/etudesirlandaises.2936

ISSN: 2259-8863

\section{Publisher}

Presses universitaires de Rennes

\section{Printed version}

Date of publication: 30 June 2012

Number of pages: 25-40

ISSN: 0183-973X

\section{Electronic reference}

Jérôme Aan de Wiel, « German Invasion and Spy Scares in Ireland, 1890s-1914: Between Fiction and Fact », Études irlandaises [Online], 37-1 | 2012, Online since 30 June 2014, connection on 01 May 2019. URL : http://journals.openedition.org/etudesirlandaises/2936 ; DOI : 10.4000/etudesirlandaises.2936 


\title{
German Invasion and Spy Scares in Ireland, 1890s-1914: Between Fiction and Fact
}

\author{
Jérôme AAN DE WIEL \\ Université de Reims/University College, Cork
}

Abstract

The impact of so-called invasion novels on Great Britain before the outbreak of the First World War in 1914 is well-known. However, it is far less known concerning Ireland. This article shows its effects, notably a confusion between fiction and fact which had serious political consequences. There was also a definite difference in the situation in both countries before the war. Yet, this kind of literature was not totally without foundation.

Keywords: invasion novels, spies, hairdressers, William Le Queux, The Invasion of 1910, Erskine Childers, The Riddle of the Sands, services secrets britanniques, Royal Irish Constabulary, Dublin Metropolitan Police, Deuxième Bureau, Irish national press, Irish regional press.

\section{Résumé}

L'impact que la littérature dite d'invasion (invasion novel) a eu en Grande-Bretagne avant le déclenchement de la Première Guerre mondiale en 1914 est bien connu. Par contre, il est nettement moins connu en Irlande. Cet article montre ses effets, notamment une confusion entre la fiction et la réalité qui a eu de sérieuses conséquences politiques, et aussi une différence certaine entre la situation en Irlande et en Grande-Bretagne avant la guerre. Cependant, cette littérature n'était pas entièrement sans fondement.

Mots clé : littérature d'invasion, espions, coiffeurs, William Le Queux, The Invasion of 1910, Erskine Childers, The Riddle of the Sands, services secrets britanniques, Royal Irish Constabulary, Dublin Metropolitan Police, Deuxième Bureau, presse nationale irlandaise, presse régionale irlandaise.

The invasion literature that developed at the end of the nineteenth and beginning of the twentieth centuries has been the object of numerous studies as it is acknowledged to have added to the increasing tensions between Britain, Germany and France leading up to the First World War in 1914. For example, in 1969, the French historian Marc Ferro wrote: "Over twenty works in England foresaw the British surprised, invaded and defeated [...]. Overall this literature reflected the nagging worries besetting the country ${ }^{1}$." Twenty-nine years later, the British his-

1. Marc Ferro, The Great War (London and New York: Routledge Classics, 2002), first published in 1969, see Chapter 4 "Imaginary War", p. 29-30. 
torian Niall Ferguson remarked about invasion novelists: "Writers like William Le Queux also played an extremely important role in the creation of Britain's modern intelligence service. An unholy alliance developed between hack writers and military careerists [...]. In any case, most of the information which Le Queux and his associates suspected German spies of trying to obtain was readily available for a small price in the form of Ordnance Survey and Admiralty maps ${ }^{2}$." Indeed, it was pure fantasy with serious consequences. While the effects of invasion and spy literature on Britain are well-known, they are far less known regarding Ireland. This study will aim to shed light on the situation in Ireland and show that on occasion fiction met fact and fact met fiction. The border between literature and reality was not always clearly drawn.

Before concentrating on fiction and facts, it is necessary to give a brief outline of the international situation between 1870 and the turn of the century. The Franco-Prussian War of 1870 saw not only the humiliating defeat of the French army by the Prussians but also the political unification of Germany, which, until then, had been divided into several states. From then on, it was clear that the newly united Germany was on her way to become the strongest military power on the continent. As to the United Kingdom of Great Britain and Ireland, it was safely away from the continent, separated by the North Sea, the English Channel and the Atlantic Ocean. The British Royal Navy had no serious rival. And yet, straight after the Prussian victory over France, a British general called Sir George Tomkyns Chesney sensed that Germany would be the power that one day would threaten Britain's very existence. Chesney was much concerned by what he deemed was British military and naval unpreparedness to face a foreign invasion. To warn public and politicians alike, he published a short book in 1871 entitled The Battle of Dorking. Although Germany is not named, the first pages of the book leave no doubt that it was her that he had in mind ${ }^{3}$.

In 1896, Kaiser Wilhelm II, the German emperor, declared that his country's destiny was on the seas. In 1898, Admiral Alfred von Tirpitz began a program to develop the German navy and catch up with the Royal Navy. It was the beginning of Germany's Weltpolitik (world policy) and also of the arms race. At first, Britain tried to reach an understanding with Germany to limit naval armament. After all, the Germans were no colonial rivals unlike the French. But soon, it was clear that Anglo-German talks would lead to nowhere. In Britain, public opinion became increasingly anti-German all the more since Imperial Germany was also becoming a major industrial and commercial rival. The British press spewed its vitriol over

\footnotetext{
2. Niall Ferguson, The Pity of War (London, Penguin Books, 1999), first published in 1998, see paragraphs "Prophets" \& "Hacks and Spooks", p. 12 \& p. 14.

3. George Chesney, The Battle of Dorking (Kessinger Publishing, 2004), first published in 1871.
} 
the Germans ${ }^{4}$. General Chesney and his Battle of Dorking seemed to be vindicated. Writers grabbed their pencils and fantasised endlessly about future invasions and wars.

The decision of the German government to step up the construction of a modern battle fleet triggered off the need to write about the future war between Britain and Germany and to portray what would be the consequences for both countries. At the beginning of the twentieth century there were about twelve invasion novels published every year ${ }^{5}$. By the time the First World War broke out in 1914, there were about 400 such books ${ }^{6}$. Other invasion stories were published by the popular press in a serialised form. Invasion gripped the minds of middle and working classes alike. There were in fact three main reasons for this literature. Firstly, the writers tried to guess what the Germans were up to. Secondly, there was the desire to make the British government want to increase military spending. And thirdly, this was the age of anticipation and imagining what the future would be. To quote Professor I. F. Clarke: "The tales of the war-to-come were part of, and had their special roles in, the great forward movement of the imagination that began about $1870^{7} \ldots ”$

The most successful of all the invasion sensationalists was without any shadow of a doubt the Englishman William Le Queux. In 1906, he published The Invasion of 1910 with the help of the prestigious Field Marshal Lord Roberts. His book portrayed the German invasion of Britain and became an international bestseller. Le Queux went on to write other books, notably Spies of the Kaiser in 1909, a particularly bad book ${ }^{8}$. Soon, he confused the border between fact and fiction and it was little wonder why the Foreign Office and War Office did not take him seriously. ${ }^{9}$ Consequently, he became an amateur spy-catcher himself. The antiGerman hysteria in Britain had of course been noticed in Berlin. In November 1904, Chancellor Bernhard von Bülow told a British journalist: "[It seems] as if a certain school of your publicists looks upon a paper-war against Germany as the main object of its life ${ }^{10}$." Little wonder.

Readers of invasion novels reported to William Le Queux on the suspicious activities and behaviour of German immigrants and tourists. The writer

\footnotetext{
4. Pierre Milza, Les relations internationales de 1871 à 1914 (Paris, Armand Colin, 2003), p. 72-76, p. 93-97 \& p. $117-118$.

5. I. F. Clarke (ed.), The Great War with Germany, 1890-1914; Fictions and Fantasies of the War-to-Come (Liverpool: Liverpool University Press, 1997), p. 1-2.

6. Tom Reiss, "Imagining the worst: How a literary genre anticipated the modern world", in The New Yorker, 28/11/2005, p. 106-114.

7. Clarke (ed.), The Great War with Germany, 1890-1914, p. 2 \& p. 5.

8. Philip Knightley, The Second Oldest Profession; Spies and Spying in the Twentieth Century (London: Pimlico, 2003) p. 17.

9. Ibid., p. 12-13.

10. Clarke (ed.), The Great War with Germany 1890-1914, p. 17.
} 
was submerged by waves of letters and to his mind they confirmed the fact that Britain was indeed being currently infiltrated by spies, preparing the dreaded invasion. People were afraid of the large number of German waiters in the country, while others spotted Germans making sketches and taking photographs. German barbers and hotel owners on the east coast were equally suspects. One man wrote to the Morning Post that there were 90,000 German army reservists in Britain and that they had hidden very exactly 209,000 rounds of Mauser ammunition. Everything was ready for the invasion, he warned ${ }^{11}$. But more importantly, little by little, owing to the pressure of public opinion and the press, the British government began to pay more attention to what Le Queux and company had to say. Although evidence of real German espionage in Britain was flimsy, the popular spy-craze eventually led to the creation of the Secret Service Bureau, later known as MI5 (domestic intelligence) and MI6 (foreign intelligence) ${ }^{12}$. At the end of the day, were there that many German spies in the United Kingdom or not? The answer is a resounding no. The British wrongly believed that not only German naval intelligence was operating in their country but also German military intelligence which was not the case. In fact, German military intelligence was focusing on France and Russia. The legendary spymaster Walter Nicolai later admitted that he would have targeted Britain but then the war broke out and it was too late to set up an efficient network ${ }^{13}$.

Having said this, there was some evidence of German intrigue. Since 1906, there had been a secret correspondence between George Freeman, a man working for Clan na Gael (Irish-American republican organisation), and Theodor Schiemann, a German professor and private adviser to Kaiser Wilhelm II. Their correspondence reveals that Freeman was sending information about Irish nationalists in Ireland and in the United States. Freeman had also extensive contacts with Indian and Middle-Eastern nationalists, opposed to British rule. In 1907, Schiemann enquired into the number of Irishmen serving in the Royal Navy, the idea being obviously to figure out whether they could be relied upon to paralyse the navy in time of war against Germany. Freeman was not able to furnish an exact number. The British did not seem to be aware of this correspondence. However, they were aware of other contacts between the Germans and Irish republicans. In 1912, the Dublin Metropolitan Police (DMP) learnt that the Irish Republican Brotherhood (IRB) had sent an emissary to meet the German ambassador in London. A short time later, the DMP learnt that Clan na Gael was sending one

11. Knightley, The Second Oldest Profession, p. 9-10, p. 16, p. 19 \& p. 20.

12. Christopher Andrew, The Defence of the Realm; The authorised history of MI5 (London, Allen Lane, 2009), p. $14-15$, p. $17-18 \&$ p. $25-26$.

13. Ibid., p. 52. 
of their men to Berlin ${ }^{14}$. It would seem that the British did have some legitimate reasons for concern. So, not only literary fantasy was at the origin of the founding of the Secret Service Bureau but also real facts. But how had the invasion scare and spy fever affected Ireland?

The Irish had one major contribution to the invasion novels: The Riddle of the Sands written by Erskine Childers in 1903. Childers came from an AngloIrish background and before he became the well-known Irish republican, he was a strong enthusiast of the British Empire. At the turn of the century, Childers became worried of a possible surprise invasion by Germany. Being a keen yachtsman he set out to explore the Frisian Isles along the Dutch, German and Danish coastline. He built the following theory. Germany had a rather short coastline facing Britain and the North Sea which would force the Imperial Navy to sail through the narrow strait of Skagerrak between Denmark and Norway. As to the Kaiser Wilhelm Canal, nowadays called Kiel Canal (since 1948) connecting the North Sea to the Baltic Sea, it was not yet deep and wide enough to allow battleships to sail through. In other words, the German Imperial Navy would be like a predictable sitting duck for the Royal Navy.

Therefore, Childers imagined that the Imperial Navy could quietly slip through the Frisian Isles, on its way to England. The problem here was that the waters around the Frisian Isles were notoriously shallow, infested with sandbanks. This forms the plot of the book. Childers imagined that the Germans were able to build special boats adapted to navigation in both around the Frisian Isles and the North Sea. But two Englishmen, Arthur Davies and Charles Carruthers, stumble across the Germans' dastardly plan and eventually foil it. The Riddle of the Sands is very technical with much attention paid to detail ${ }^{15}$. And this is the main difference with all the other invasion authors. Childers' book is widely regarded as the first modern thriller, a precursor of Frederick Forsythe, John Le Carré, Robert Ludlum and so on. In 1979, the book became a film of the same name by Tony Maylam. In 1987, there was a version for the German television called Das Rätsel der Sandbank (the mystery of the sandbank) by Rainer Boldt. In November 1903, the Irish Times (unionist) commented: "[...] the story, viewed from both points, whether that of politics or adventure, is an interesting and exciting one. Mr. Childers has a very facile pen, and will be heard of again ${ }^{16}$." Indeed.

The Riddle of the Sands was an instant success. Childers himself expressed the hope that "nobody will read into this story of adventure any intention of provoking feelings of hostility to Germany". The main purpose of the book, he explai-

14. Jérôme aan de Wiel, The Irish Factor, 1899-1919; Ireland's strategic and diplomatic importance for foreign powers (Dublin, Irish Academic Press, 2008), p. 48-49, p. 135-139 \& p. 57-58.

15. Erskine Childers, The Riddle of the Sands (London, Penguin Books), first published in 1903.

16. The Irish Times, $07 / 11 / 1903$. 
ned, "is to stimulate interest in a matter of vital importance to Great Britain". It was above all meant as a warning. It did just that. The very same year, the Conservative government of Prime Minister Arthur Balfour announced the setting up of a new Royal Navy base at Rosyth in Scotland ${ }^{17}$. Winston Churchill admitted that The Riddle of the Sands was at the origin of the establishment of further bases at Invergordon, Firth of Forth and Scapa Flow ${ }^{18}$. It looked pretty much as if Childers was playing his part in the current arms race between Britain and Germany. But then followed a rather bizarre episode, once again evidence that fact and fiction were blurred. In August, two British officers, Captain Trench and Lieutenant Brandon, were arrested by the Germans on the Frisian island of Borkum. They had been sent there by British naval intelligence ${ }^{19}$. In December, they were put on trial in Leipzig and condemned to a prison sentence. It then transpired that Brandon had read The Riddle of the Sands not less than three times... Childers would later meet the two spies $^{20}$. Even Churchill drew his strategic inspiration from the book when the war broke out in August 1914. He was then First Lord of the admiralty and argued during a cabinet meeting that the Royal Navy should seize one of the Dutch Frisian islands. ${ }^{21}$ It was never carried out and the chances were that if the Royal Navy had done so, it would have made sure that the neutral Dutch would have joined the Germans in the war. As to Childers, he went sailing again in the North Sea, near the Kiel Canal and in German territorial waters in the summer of 1913 but he felt that he was no longer welcome there ${ }^{22}$. No wonder.

But what was the situation in Ireland? The reality was that Germany was badly known. Therefore, the image that people had of that country was rather vague and this facilitated the task of propagandists ${ }^{23}$. While this is certainly correct, a survey of twelve Irish newspapers between 1890 and 1914 allows to state that invasion and spy scares were above all reported by the national press rather than by the regional press. For instance, the term "German invasion" is found 96 times in the Irish Times, 61 times in the Irish Independent and 33 times in the Freeman's Journal as opposed to 12 times in the Southern Star, 10 times in the Leitrim Observer and 9 times in the Anglo-Celt. The term "German spy" is reported 105 times in the Irish Times, 34 times in the Irish Independent and 14 times in the Freeman's Journal as opposed to 6 times in the Southern Star, 5 times in the Leitrim Observer and 3 times in the Connacht Tribune. Also of interest are the following facts. The Riddle of the Sands is mentioned only twice in the Irish Indepen-

17. Clarke (ed.), The Great War with Germany 1890-1914, p. 3 \& p. 10.

18. Knightley, The Second Oldest Profession, p. 16.

19. Andrew, The Defence of the Realm, p. 32.

20. Jim Ring, Erskine Childers: Author of the Riddle of the Sands (London: John Murray, 1997), p. 119 \& p. 127.

21. Ibid., p. 153.

22. Ibid., p. 131.

23. Joachim Fischer, Das Deutschlandbild der Iren 1890-1939 (Heidelberg, Winter, 2000), p. 49. 
dent, once in the Sunday Independent and once in the Irish Times. The Invasion of 1910 is mentioned 6 times in the Irish Times, once only in the Anglo-Celt, the Connacht Tribune and the Meath Chronicle. However, William Le Queux is mentioned 109 times in the Irish Times, 20 times in the Irish Independent, twice in the Sunday Independent and once in the Meath Chronicle. His name also appears 12 times in the Leitrim Observer although in advertisements for a new book of his, The Money Spider (about a mystery set in the Arctic) ${ }^{24}$. Evidently, before the war, unlike what was happening in Britain, fear of Germany seems not to have been as virulent in Ireland simply because she had no quarrel with Germany but definitely had one with Britain about home rule.

The Irish press did however make some publicity for and offer literary criticism of invasion novels. In October 1906, the Irish Independent commented on Ernest Oldmeadow's The North Sea Bubble that it was "a remarkable book" 25. Perhaps had the newspaper been inspired by the fact that the decisive battle in Oldmeadow's imagination takes place at the Shannon river in Ireland and which sees the ultimate defeat of the Germans by the Anglo-Irish army. Was it a subliminal message against home rule? The Irish Independent had also much good to say about Alan H. Burgoyne's The War Inevitable published in 1908. This book depicts "a treacherous German invasion of England, secretly planned during the illness of the German Emperor". Yet, the combined Anglo-Japanese forces eventually defeat the Teutonic invaders ${ }^{26}$. But some Irish newspapers could be most critical of the mass hysteria that invasion scares had produced in Britain. Perhaps one of the most trenchant articles was published by the Anglo-Celt in March 1909. It stated that the English people had worked itself into "a state of agitation" and severely, but also rightly accused the British press of spreading falsehoods on Germany and her Kaiser, particularly Lord Northcliffe's newspapers:

The papers conducted by Lord Northcliffe - Mr Harmsworth that was - raised the cry of a contemplated German invasion - the presence of 50,000 clerks, waiters and others of that Nationality in London alone giving a good foundation for the powers of the imaginative journalist.

24. Research carried out by search engine in the Irish Newspaper Archive, www.irishnewsarchive.com, and the digital archive of the Irish Times, www.irishtimes.com/search/archive.html (consulted on 02/02/2010). The following newspapers were used: The Freeman's Journal, The Irish Times, The Irish Independent, The Sunday Independent, The Anglo-Celt, The Connacht Tribune, The Leitrim Observer, The Munster Express, The Nenagh Guardian, The Southern Star, The Meath Chronicle \& The Westmeath Examiner. It should be noted that the Cork Examiner and a main unionist newspaper from Ulster are not included. However, there is no much reason to believe that the findings would have been significantly different if they had been included. The time range used is from 1 January 1890 until 31 December 1914. Curiously, research in newspapers with the search engines does not always return the same results, but it remains largely relevant nonetheless.

25. The Irish Independent, 01/10/1906.

26. Ibid., 16/11/1908. 
[...] This sort of stuff has resulted in a war-scare in England, the masses being genuinely apprehensive that at any moment the German fleet may batter their cities to ruins, and subject them to a hateful yoke ${ }^{27}$.

The Anglo-Celt then opportunistically, but also realistically informed its readers that if war was on the cards between Britain and Germany, then the British government would do well to quickly satisfy Ireland's home rule aspirations ${ }^{28}$ ! The more extreme nationalist press, however, was taking sides with Imperial Germany. In 1905, the United Irishman declared: "It has been English policy to represent the German Emperor - in Ireland - as a shouting idiot - a policy helped by our imitative and slavish press. The German Emperor is an astute monarch, who has trumped every card which England has played against Germany in Africa, in South America, and in Europe." In 1908, Arthur Griffith, the founder of Sinn Féin, praised the Kaiser's foreign policy in Sinn Féin and approved of Berlin's decision to increase naval expenditure ${ }^{29}$.

Then, there were those Irishmen who did not like their tax money to be spent on the building of dreadnoughts for the Royal Navy. In March 1909, the Irish Times reported that at a meeting of the United Irish League (UIL) in Drogheda, it was suggested that if Ireland had home rule, she would be very glad to build a dreadnought for the Royal Navy, just like New Zealand was currently offering to do. But some UIL members did not agree. One believed that building navy ships was none of Ireland's concern, only home rule was, and another said that the German invasion scare was "only a political fake, got up to force the [British] Liberal party to spend money ${ }^{30 "}$. In April, the Meath Chronicle wrote about the recent meeting of the Dunshauglin Board of Guardians that a Mr Fitzsimmons had put forward an amendment against the raising of additional taxes on Irishmen which would serve to build more dreadnoughts, quick firing guns, submarines and so on. He had added: "[...] As we are not afraid of any German invasion in this country, we refuse to be a party to any further suicidal taxation." Fitzsimmon's amendment was ruled out ${ }^{31}$, but, as will be seen, he was not wrong.

Although, the German invasion and spy fever was definitely milder in Ireland, it did nonetheless enter the people's psyche. In April 1909, the Freeman's Journal reported that a German spy had been sighted at Kilmallock in County Limerick. He was never found, however ${ }^{32}$. In November 1912, the Irish Independent reported that a suspicious man was seen camping near a fortified position in Galway.

\footnotetext{
27. The Anglo-Celt, 20/03/1909.

28. Ibid.

29. aan de Wiel, The Irish Factor, 1899-1919, p. 51-52.

30. The Irish Times, 25/03/1909.

31. The Meath Chronicle, 24/04/1909.

32. The Freeman's Journal, 16/04/1909.
} 
He was arrested and it subsequently turned out that he was a Belgian tourist of a well-known family ${ }^{33}$. The following year, still in Galway, the Connacht Tribune reported that a mysterious airship had been spotted by the inhabitants. The newspaper recorded their reactions: "Many people were startled by the rumour, and drew highly imaginative pictures of a German invasion, evidently an echo of the recent airship scare in England ${ }^{34}$." Unsurprisingly, on occasion journalists used the invasion image in articles which had nothing to do with the actual subject. In May 1907, the Irish Times reported on rumours regarding the establishment of a shipping line between Liverpool and New York by the German shipping company Hamburg-America Line. It titled: "Liverpool and New York Trade; the German invasion 35 ." It was the same story with the Irish Independent. In April 1909, it wrote about the threat that German trawlers posed to Ireland's fisheries. The eyecatching title of the article was "A German Invasion; Irish fisheries in peril ${ }^{36 "}$. Without a doubt, such titles could not have failed to influence some people's opinions and did much to increase their ill-defined fear of Germany.

Interestingly, some felt the urge to personally write to Kaiser Wilhelm II. In 1907, somebody in England, very likely an Irishman or woman, sent him the following postcard: "To the German Emperor. Should you invade England in 1910, you will not harm the Catholic churches, will you? A happy Christmas ${ }^{37}$ ! But in Ireland, there was a unique phenomenon as some among the nationalists but also unionists were ready to welcome a German invasion. In 1905, a Protestant woman urged the Kaiser to deliver Ireland $[s i c]$ from the tyranny of the organised Roman Catholic rule, now existing in the west of Ireland. [...] In the name of God come over and deliver us. [...] Why should not a German be Lord Lieutenant of Ireland! Amen ${ }^{38}$." This was the irony: on the one hand, there were unionist leaders who declared that they would prefer the Kaiser's rule rather than nationalist Rome rule while on the other hand, advanced nationalists were thinking of an alliance with Germany to get rid of the British! In 1909, the Kilkenny People reported that Major John MacBride, an Irish republican who had fought with Boers against the British in South Africa, had said that in case the Germans invaded Britain he hoped that they would also send 100,000 rifles to Ireland for her liberation. In 1910, however, Thomas Andrews, a member of the Ulster Unionist Council, told the very proConservative Morning Post that he would "rather be governed by Germany than by Patrick Ford and John Redmond [home rule party leader] and $\mathrm{Co}^{39}$ ". The question

33. The Irish Independent, 21/11/1912.

34. The Connacht Tribune, 29/03/1913.

35. The Irish Times, 28/05/1907.

36. The Irish Independent, 30/04/1909.

37. aan de Wiel, The Irish Factor, 1899-1919, p. 25.

38. Ibid., p. 52.

39. Ibid., p. 24 \& p. 52. 
was: who would get Germany's favour?! The answer seemed to be both. Indeed, in April 1914 the Ulster Volunteer Force (UVF) smuggled German arms into the country during a daring gun-running operation and it was followed by a gun-running operation of the Irish Volunteers the following July. The irony here was that it was Erskine Childers, by now a committed Irish nationalist, who transported the German rifles on his yacht ${ }^{40}$ ! It could be said that his writing of The Riddle of the Sands had provided him with enough experience. Fiction was becoming fact.

It came as no surprise that all these pro-German declarations and gun-running activities began to seriously worry the authorities in Britain and Ireland. In April 1910, the Dublin Metropolitan Police (DMP) mounted a surveillance operation regarding a certain German professor called Krautwurst. Krautwurst had acquired a house in Sandymount at 17 Strand Road. He had committed no crime but the problem was that his house was "a substantial dwelling facing the sea"... If you were foreign and came from Central Europe, the location of your home or place of work could become problematic. In January 1914, the Irish High Command took the decision to restrict the movements of a German national called Bessler who owned the Salthill Hotel in Monkstown simply because it was near the sea. From now on, Bessler needed a special permit to enter "the prohibited area of the county of Dublin" to visit his family. It was the same with an Austro-Hungarian national called Spacek who was the manager of the Royal Marine Hotel in Kingstown (nowadays Dun Laoghaire) ${ }^{41}$. In December 1913, the Royal Irish Constabulary (RIC) reported to Vernon Kell, the head of MO5 (called MI5 in January 1916), the whereabouts of a real German spy, Captain Kurd von Weller, who would be arrested in August 1914 ${ }^{42}$. But then, like in Britain, the barber conspiracy began. In Spies of the Kaiser, William Le Queux had written that one spy was a barber. This turned out to be a source of inspiration for Colonel James Edmonds of the British Secret Service, who kept an eye on two German hairdressers in Southsea, one of them, it "was discovered by accident" was wearing "a wig over his own thick head of hair 43 ". Soon what would nowadays be termed a conspiracy theory blew over to Ireland.

In January 1914, the detectives of the DMP had noticed what were believed to be suspicious activities of two German hairdressers, Karl Schmutz and Ernest Heise. Schmutz had joined an Orange Order lodge in Dublin while Heise was in touch with Sinn Féin. In this case, it would seem that the police was rather justified in being intrigued. Indeed, why should two immigrants do so? The chief inspector of the DMP concluded pertinently:

40. Ibid., p. 69-72, p. 33-34 \& p. 36-37.

41. Ibid., p. $52 \&$ p. 67-68.

42. Andrew, The Defence of the Realm, p. 875 (endnote 112).

43. Knightley, The Second Oldest Profession, p. 19-20. 
It is remarkable that Schmutz and Heise should be identified with two sections of Irishmen who would likely create extreme political strife; and from all the surroundings I respectfully suggest that it is reasonable to assume that the two men named are agents for and in the pay of the German Government ${ }^{44}$.

It might be relevant to point out here that when the war broke out, 22 German agents (real ones!) were immediately arrested and three of them, Karl Gustav Ernst, Frederick William Fowler and Otto Moritz Walter Kruger, were hairdressers ${ }^{45}$. So, was there a barber conspiracy after all? It is quite clear that barber shops and restaurants located near naval bases for instance could be ideal spots to pick up information and gossip. It should also be mentioned that the Prussians did use some German immigrants in France to prepare their invasion in 1870. Some of them were teachers, waiters and barbers. The British had concluded that the Prussians had used German army reservists in France. Besides, some German military reviews like the Militärwochenblatt, which the British read, had explained the need for saboteurs and spies ${ }^{46}$. However, this did obviously not mean that every single hairdresser and waiter was a spy unlike what was believed.

But, in this long saga of fiction meeting fact, there was a twist, and a big one as it turned out. When Erskine Childers wrote The Riddle of the Sands in 1903, he was right to warn his readers about a possible invasion, but he got the enemy wrong: it was not the Germans but the French! Indeed, two boxes of documents in the French military archives near Paris reveal that some French officials seriously toyed with the idea of attacking Britain through Ireland at a time when the British army was away in distant South Africa (incidentally, there are no documents about a German invasion in the German military archives in Freiburg im Breisgau). Between 1900 and 1904, several French intelligence agents were sent to Ireland to explore the possibility of a landing. Ireland was of course a historic ally of France. The agents sent back very precise reports to the Deuxième Bureau (military intelligence) in Paris about topography, quality of the roads, British coastal defences, strength and morale of British troops, estimations of strength and quality of various nationalist and unionist organisations and so on. The agents had reached the conclusion that the southern coast in County Cork would be the best place to land. They were in touch with Irish republicans who gave them a detailed invasion plan in September 1902. Of course, for the republicans an attack on Britain through Ireland would lead to the liberation of their country, so they hoped. On occasion very precise questions were put by the French. For

44. aan de Wiel, The Irish Factor, 1899-1919, p. 68-69.

45. Andrew, The Defence of the Realm, p. 38 \& p. 873-875 (endnote 112).

46. Ibid., p. 11. 
instance, what would the Irish people do in the event of a joint Franco-Russian invasion? No names, be they French or Irish, were ever mentioned in the reports for the Deuxieme Bureau. Security concerns were paramount and yet the German embassy in Paris got wind of rumours of a French invasion of Ireland and warned the Foreign Office in Berlin. The rumours, however, were wrongly dismissed.

But there was more. The British Special Branch had infiltrated Clan na Gael in the United States. In December 1900, one of its agents reported to London that John MacBride had arrived in New York by way of Paris. In a subsequent secret meeting, MacBride told John Devoy, the leader of Clan na Gael, and a few others that he had recently been "brought to see the leading Minister of the Government in Paris by a well known Deputy, and the question asked him by the Minister was, what would the Irish be prepared to do in say six months or when called upon in conjunction with [France] [...]". The identity of the two Frenchmen remains an enigma although hints would point to René Waldeck-Rousseau, the Prime Minister, and Lucien Millevoye, a French deputy who was the lover of MacBride's wife, Maud Gonne, despite the fact that Waldeck-Rousseau was from the left and Millevoye from the far-right. The French, German and British sources all fit together like a jigsaw and there can be no doubt that some in Paris had indeed considered attacking Britain through Ireland. But it never materialised. In April 1904, France and Britain signed the Entente Cordiale, which also explained why Irish republicans turned towards Germany as a potential source of support. It is most relevant to notice that after the signing of the Entente Cordiale, French military intelligence immediately lost all interest in Ireland as the sudden lack of documents in the French military archives shows. It was the big hint that confirmed the hard evidence that an invasion had indeed been seriously envisaged ${ }^{47}$.

But with the big twist came a big irony. It was William Le Queux of all people who got the name of the plausible enemy right since in 1903, the very same year Childers published The Riddle of the Sands, he pointed the finger at France in his novel Secrets of the Foreign Office. If only his imagination had known how close to the truth he came! A final observation here. Professor Christopher Andrew, specialist in the history of espionage and author of a seminal study of MI5, has written that the leaders of the British Secret Services "had much better grounds for believing that there was a major German espionage offensive against Britain than most historians [including himself] have been willing to recognize ${ }^{48}$ ". The French invasion episode definitely confirms Andrew's view except that the British were looking across the North Sea and not the English Channel.

\footnotetext{
47. Jérôme aan de Wiel, "The French Invasion that never was: the Deuxième Bureau and the Irish Republicans, 19004", in Nathalie Genet-Rouffiac \& David Murphy (eds.), Franco-Irish Military Connections, 1590-1945 (Dublin, Four Courts Press, 2009), p. 238-252 \& aan de Wiel, The Irish Factor, 1899-1919, p. 3-25 \& p. 124-129. 48. Andrew, The Defence of the Realm, p. 10-11.
} 
When the war eventually broke out in August 1914, spy fever reached unprecedented heights of delusions in Britain. The facts are well known and do not need to be detailed here ${ }^{49}$. The government at once passed drastic legislation to cope with spying. The Aliens Restriction Act allowed the authorities "to impose restrictions on aliens and make such provisions as appear necessary or expedient for carrying such restrictions into effect". It was followed by the Defence of the Realm Act (DORA) which was almost the equivalent of martial law powers. Home Secretary Reginald McKenna did not manage to assuage the public's obsession despite the fact that the German spy network had already been smashed with the arrest of 22 spies. The British press was not convinced either by the efficiency of governmental measures ${ }^{50}$. Ireland too was in the grip of war fever. Civil war between nationalists and unionists regarding home rule had been averted thanks to a last-minute compromise solution found by Herbert Asquith's cabinet: home rule was put on the statute book and would be implemented after the war, which everybody believed would be short, and a solution would have to be found for Ulster. Nationalists and unionists went to war together, but republicans, Sinn Féin and the Irish Labour Party did not agree.

In August, the inspector-general of the RIC wrote: "All classes displayed a strong patriotic and anti-German feeling, and joined irrespective of creed and politics in giving a hearty send off to the Reservists when they left to join the Colours $^{51}$." Recruitment figures were outstanding. Between 4 August 1914 and February 1915, about 50,107 Irishmen volunteered to fight in the British army and left for the trenches of France. The press was largely in favour of the war. The Cork Examiner published strategic maps to keep its readers posted ${ }^{52}$. The Irish Times opined that a German invasion in the north of the country was unlikely, owing to the presence of the well-trained Ulster Volunteer Force (UVF). Therefore, the southern and western coasts would be better options for them, but 150,000 well-trained men could repulse them ${ }^{53}$. The Irish Independent thought it judicious to re-advertise The Riddle of the Sands to explain the crisis ${ }^{54}$. The Sunday Independent divulged that Erskine Childers was to serve with the Royal Navy in the North Sea and commented: "The author of The Riddle of the Sands, which, more than any other argument, was the cause of strengthening England's naval power in the North Sea, will surely give us a great story when the great war is

\section{Ibid., p. 53.}

50. Ibid., p. 53-54.

51. Jérôme aan de Wiel, The Catholic Church in Ireland, 1914-1918: War and Politics (Dublin, Irish Academic Press, 2003), p. 1-7.

52. aan de Wiel, The Irish Factor, 1899-1919, p. 160-161.

53. The Irish Times, 28/08/1914.

54. The Irish Independent, 21/08/1914. 
at an end ${ }^{55 . "}$ In this the Sunday Independent was seriously mistaken as Childers would devote his energy to Ireland's struggle for independence.

As could have been easily predicted, spy fever took hold of the masses, far more than what had happened before the war. The Freeman's Journal reported that in Ballina "two persons dressed in clerical garb were arrested [...] and detained in a barrack" while outside a hostile mob had gathered. It turned out that the two men with strange accents were in fact Scottish priests ${ }^{5}$ ! The Kerryman reported that local fishermen had been shot at by soldiers as their boat had approached a British naval base near Berehaven. One of them had been hit in the leg. Sketching had become a most dangerous activity. The Galway Pilot and Vindicator wrote that a man had been seen sketching near Nimo's Pier in Galway. He was arrested on the spot but it later transpired that he was from Dublin. The Galway Express rightly commented: "It is rather unpleasant to be a stranger in Galway at present, especially if your physiognomy presents a cosmopolitan appearance ${ }^{57}$." The Irish Independent had a story about a young man who was seen cycling between Bray and Enniskerry. The police found it suspicious and arrested him. He was only an English tourist ${ }^{58}$. The Meath Chronicle warned against German balloons, Zeppelins, allegedly seen flying over Drogheda ${ }^{59}$.

In Ireland, the Aliens Restriction Order applied too. The German community in the country was very small. The census of 1911 recorded 963 nationals ${ }^{60}$, but some Germans and Austro-Hungarians were rounded up and interned although it remains difficult to give an exact figure. The Cork Examiner reported that nine men in Cork and seven in Limerick, including two women, were detained by the army. In Dublin, like in London, Liverpool, Manchester and elsewhere, angry crowds smashed windows of shops owned by Germans ${ }^{61}$. In Britain, about 8,000 aliens faced police investigations but there was no proof whatsoever of an undercover German military network ${ }^{62}$. The Irish Independent welcomed these tough measures on aliens. The newspaper was still convinced that a threat existed and considered it a chance to give jobs back to the Irish people and rid the country of foreigners: "One effect of this policy, which will, doubtless, be extended to Ireland, will be that Irish waiters, hairdressers, and other servants will have a better chance of securing employment at reasonable wages in their own country ${ }^{63}$."

\footnotetext{
55. The Sunday Independent, 20/09/1914.

56. aan de Wiel, The Catholic Church in Ireland, 1914-1918, p. 4.

57. an de Wiel, The Irish Factor, 1899-1919, p. 161.

58. The Irish Independent, 07/08/1914.

59. The Meath Chronicle, 17/10/1914.

60. Fischer, Das Deutschland Bild der Iren 1890-1939, p. 43 \& p. 621.

61. aan de Wiel, The Irish Factor, 1899-1919, p. 161-162.

62. Ferguson, The Pity of War, p. 14.

63. The Irish Independent, 19/10/1914.
} 
And so 1914 ended, on a very high note in favour of the war. But unlike in Britain, the invasion scare, spy fever and pro-war atmosphere in Ireland would not last. There were a variety of reasons for this. In a nutshell, the leader of the constitutional Nationalist Party, John Redmond, had many difficulties with the War Office in London which was slow in recognising and exploiting Irish patriotism and the bravery of Irish soldiers at the front. Recruitment campaigns were badly organised and the anti-war nationalists and republicans began to mount an effective anti-war campaign. Anti-allied, especially anti-French propaganda spread in the country. Already by the summer of 1915, the inspector-general of the RIC noticed that recruitment figures were seriously dropping. Many farmers refused to enlist and enjoyed the current economic prosperity engendered by the war, a kind of a proto Celtic Tiger. People simply got on with their lives and a kind of political apathy took hold of the masses. The Easter Rising of April 1916 and its consequences made sure that recruitment remained moribund, and that the people took no longer much active interest in the war $^{64}$.

In conclusion, although there were invasion scares and spy fever in Ireland fuelled by a literature that gripped the people's imagination, the situation was not as virulent as in Britain before the First World War. This was mainly due the different political climate as Irish nationalists were struggling for home rule. Not all of them perceived Germany as being the next enemy, the more advanced nationalists even thinking of a possible alliance with Berlin. The last point materialised during the war and its outcome was of course the Easter Rising in 1916. There was therefore a political counterweight to invasion literature that was certainly far stronger than in Britain. The following example illustrates this. In 1909, Captain Guy du Maurier wrote a play entitled An Englishman's Home about the German invasion of Britain. The play was a major success in London and was a message in favour of compulsory military service ${ }^{65}$. But in Dublin, it seemed to have been a different story. The play was performed in the Theatre Royal and the Gaelic American, Clan na Gael's newspaper, reported that when the German soldiers arrived on stage, the audience shouted: "You're welcome, Boys!, Long live the Kaiser, Three Cheers for our Friends the Germans, Avenge the Concentration Camps of South Africa [sic]." The German embassy in Washington was visibly impressed by this as it sent the Gaelic American's article to Berlin for further analysis. The German Foreign Office underlined the relevant passages ${ }^{66}$.

Also, the pro-home rule press, and not necessarily extremist newspapers, had correctly guessed that invasion novels served to increase Britain's military budget. In fact, Admiral Jackie Fisher, the Royal Navy's first sea lord, reflecting on the novels

64. aan de Wiel, The Irish Factor, 1899-1919, p. 170-172, p. $180-183$, p. $196-199$, p. $240-241$, p. $294-295$ \& p. 302-306.

65. Clarke (ed.), The Great War with Germany, 1890-1914, p. 17-18.

66. aan de Wiel, The Irish Factor, 1899-1919, p. 51. 
said: "[They] served the double purpose of supplying false information to subserve expansion of armaments, and of increasing the ill-feeling which had already been worked up between England and Germany ${ }^{67}$." On 20 March 1909, the Anglo-Celt wrote a pertinent article entitled "A German Invasion" in which it denounced the British government's opportunistic attitude and ridiculed the novels:

Some men succumb to flattery from a political opponent, and evidently Mr. Haldane [Liberal secretary of state for war] is one of these. He fell in with [the Conservative and Unionist newspapers'] suggestions as to the new Territorial forces and they in return engaged capable novelists to write realistic stories of the capture of England by the Germans within their walls, telling how on a certain Sunday night they cut the telegraph and telephone wires, took possession of a Dreadnought through the action of a German chef and attendants aboard, murdered the most prominent financier in England, captured the Prime Minister, rendered useless the ammunition intended for British troops and placed the capital of England under foreign rule ${ }^{68}$.

There can be little doubt that a certain press in Britain and Germany prepared the public for war and therefore bore some responsibility in its eventual outbreak in August 1914. It must be noted here though that those who were in favour of more military expenditure in Britain were successful only to some extent. For instance, the idea of compulsory military service was not politically popular. Conscription would only be introduced in Britain during the war at the beginning $1916^{69}$. Ireland would then be left out because of political considerations. A last point of interest. After the Easter Rising, the British sent the $59^{\text {th }}$ division to Ireland to control the country. In September 1916, it participated in military manoeuvres. The order of the division was: "Any German troops south of the Liffey [river near Dublin] are to be vigorously attacked." It was an order that had little relation with reality as the battle of Jutland on 31 May 1916 had clearly demonstrated that the German navy would not break the blockade imposed by the Royal Navy in the North Sea. But as the French military attaché in London wrote much to his frustration: "No matter how unlikely the landing of important enemy forces with all their equipment is, there are, however, people, and serious people, who do not dismiss out of hand such a hypothesis ${ }^{70}$." Would it be exaggerated to suggest that The Riddle of the Sands and The Invasion of 1910 were still at work here?

67. Knightley, The Second Oldest Profession, p. 28.

68. The Anglo-Celt, 20/03/1909.

69. Ferguson, The Pity of War, p. 15-16, p. 102-104 \& p. 198.

70. aan de Wiel, The Irish Factor, 1899-1919, p. 220-221. 